\title{
Body Responses to Combination of Endurance and Strength Training for Kids Aged 13-14 Years Old
}

\author{
Danang Wicaksono \\ Fakultas Ilmu Keolahragaan \\ Universitas Negeri Yogyakarta \\ Yogyakarta, Indonesia \\ danang_wicaksono@uny.ac.id
}

\begin{abstract}
Young boys experience increased hormonal changes at about thirteen to fourteen years of age that is why they grow fast. This study observes body responses to a combination of endurance and strength training among children at age of thirteen to fourteen years old. As a preexperimental study, it applied a One Group Pretest-Posttest Design. Samples of this research were fifteen male volleyball athletes aged thirteen to fourteen years old. For data collection purpose, tests and assessments were carried out. The test instrument concerned the "back and led dynamometer" for the assessment of limb and back muscle strength, "pool and push dynamometer" for the assessment of shoulder muscle strength, and "multistage fitness test" for the assessment of aerobic fitness. During sixteen meetings, treatments were given using Interval training process for a combination of endurance and strength training. The training involved an addition of a fivekilogram iron equipment and was conducted in sand volleyball court at $60 \%$ to $70 \%$ of maximum heart rate. To analyze the data, this research adopted a t-test analysis after a set of assumption test. The results show the major influence of a combination of endurance and strength training on increased motor ability along with aerobic fitness with 3.60 of t-test value, $0.003<0.05$ of significance level, and an increase of $9.62 \%$. though, a significance level $>0,005$ indicates no significant influence on biomotor strength.
\end{abstract}

Keywords-body responses, combination of endurance and strength training, kids aged 13-14 years old.

\section{INTRODUCTION}

Systematically arranged training is used as among the ways to improve athletes' physical condition. For the best results, training methods ought to be carefully selected. It is also necessary to maximize the development of athletes' basic physical condition like strength, speed, endurance, coordination, as well as balance to support their performances. Strength and endurance both are fundamental components that are very important in all sports.

It requires a long time to create an athlete using scientific training approach. Training is conducted constantly, systematically, and progressively in a particular period of time to boost physical components that support the performance. Physical training can be performed either separately or simultaneously by using a training combination. In most sports, a combination of strength and endurance training is needed to improve performance. Though, in certain situations, performing strength and endurance training at the same time potentially cause disruption that makes such.

Combination incompatible [1]. There are also proofs indicating that endurance training blocks the development of maximum strength, particularly a few weeks after the training combination starts [2]. Some studies determined that endurance training blocks or disrupt strength development $[3,4,5]$.

During training at age thirteen-14 years, male athletes start experiencing quick physical grows. A fairly fast increase in height is caused by physiology and hormonal process inside their body. Athletes have become the subjects of many studies. Though, not many studies focus particularly on young boys aged 13-14 years old. Biological maturity status significantly influences the functional capacity of young male football players aged thirteen-15 [6]. The testosterone becomes important for strength development among teenage boys [7]. To that extent, do a combination of strength and endurance training for male athletes aged thirteen-fourteen years give positive influence? In other words, what responses will human body give to a combination of strength and endurance training for male athletes aged thirteen-fourteen years?.

\section{THEORY}

\section{A. Body responses}

Human body will react to any external and internal stimulation as well as training is one of external stimulations that influence human body. Continuously produced responses might improve the quality of the human body is responding to stimulation. A training process is expected to produce positive body responses in form of body adaptation to boost the quality of the body's physiological works.

\section{Combination of aerobic fitness and strength training}

Cardiorespiratory endurance is one of the essential components in physical fitness [8,9]. In this study, the aerobic fitness training was performed at an average intensity or $60 \%$ to $70 \%$ of maximum heart rate and using an interval training type. The training is performed in a sand volleyball court and making use of the long side of the court. It performed many basic moves such as combinations of stepping, walking, and also jogging.

The aerobic activities are combined with the strength training and utilizing an addition of a 5-kilogram iron equipment. The interval-type aerobic activities are performed along the volleyball court utilizing a combination of moves of the upper body, trunk, and lower body parts at $60 \%$ to $70 \%$ 
training zone and an addition of a $5-\mathrm{kg}$ iron equipment. (Figure 1).
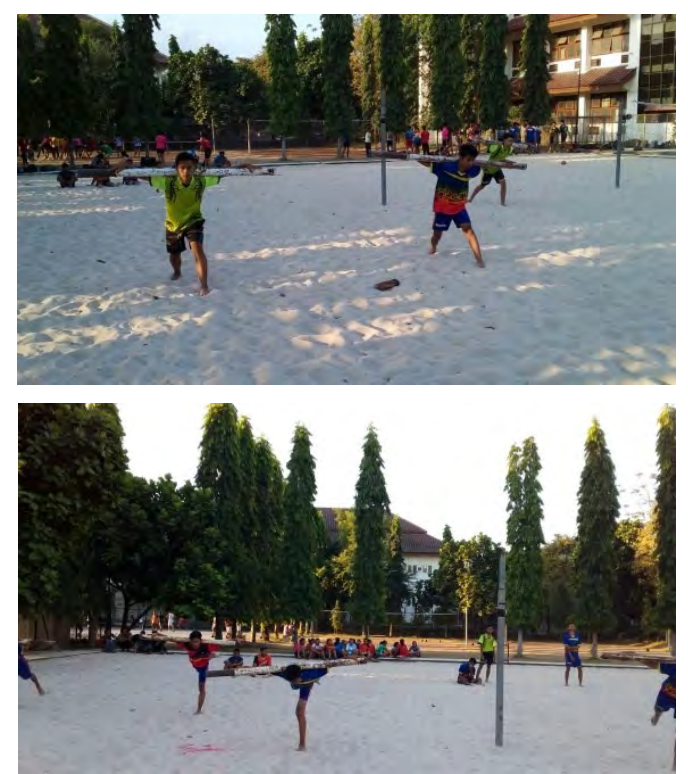

Fig. 1. Sample of the combination of endurance and strength training

Combining endurance and strength training means performing endurance training and strength training simultaneously. Aerobic fitness comes from maintaining the training zone at $60 \%$ to $70 \%$ of maximum heart rate. Meanwhile, strength training results from combining moves with iron equipment.

\section{Young Ones Aged thirteen-fourteen Years Old}

At the age of thirteen to fifteen years, teenagers physically grow faster than when they are at the pre-teen phase. By the age of thirteen-fifteen years, teenagers enter their early teens. This phase may possibly be the when rapid changes, such as fundamental changes in cognitive, emotional, social, and physical aspects, take place.

With no muscle flexibility training, the growth of body muscles potentially causes stiffness. Especially for men, physical development usually starts at pre-teenage years and goes much faster during early teenage before getting to its peak in mid as well as late teenage [10].

Changes are marked by increases in body weight and height, bone and muscle growth, and maturity of sexual organs as well as reproduction functions. At the same time, sexual organs of teenagers aged thirteen-fifteen begin growing biologically at a much faster rate. These changes make the sexual hormones grow as well.

The top height speed among young girls usually happens by the age of 12 and by the age of fourteen for young boys. Growth among girls usually stops by the age of 16 and by the age of eighteen for boys. As they get older, the growth of height is usually closer to its end. At this point, their sexual steroid hormone also affects the maturity of their bone at epiphyseal plates. During late puberty, the epiphyseal plates will close and therefore stop the growth of body height $[11,12]$

By the age of 13-14, teenagers experience significant hormonal changes like changes will influence the adaptation process of the body. The body will respond to any given training (in this case is the combination of aerobic fitness and strength training).

\section{METHODS}

As a pre-experimental study, it applied a One Group Pretest-Posttest Design. Samples of this study were 15 male volleyball athletes aged 13-14 years old. For data collection purpose, tests and assessments were performed. The test instrument included the "back and led dynamometer" for the assessment of limb as well as back muscle strength, "pool and push dynamometer" for the assessment of shoulder muscle strength, and "multistage physical fitness test" for the assessment of aerobic fitness. During 16 meetings, treatments were given using Interval training method for combination of endurance as well as strength training. The training required an addition of a $5-\mathrm{kg}$ iron equipment and was performed in sand volleyball court at $60 \%$ to $70 \%$ of maximum heart rate. To evaluate the data, this study adopted a t-test analysis after a few assumption tests.

\section{RESULTS AND DISCUSSION}

\section{A. Description of Research Results}

Research results are presented based on the statistical analysis performed in the pre-test and posttest of physical biomotor abilities (physical biomotor abilities of limb muscle strength, back muscle strength, shoulder muscle strength, as well as aerobic fitness).

TABLE I. DATA DESCRIPTION OF MEAN DIFFERENCES IN AN INCREASE OF PHYSICAL BIOMOTOR ABILITIES. TEST RESULTS ARE PRESENTED AS FOLLOWS:

\begin{tabular}{|c|c|c|c|c|}
\hline No & Biomotor & $\begin{array}{c}\text { Mean } \\
\text { pretest }\end{array}$ & $\begin{array}{c}\text { Mean } \\
\text { posttest }\end{array}$ & $\begin{array}{c}\text { Difference } \\
\text { of mean }\end{array}$ \\
\hline 1 & Leg strength (kg) & 159,3 & 182.4 & 23,1 \\
\hline 2 & Back strength (kg) & 97,5 & 106,1 & 8,7 \\
\hline 3 & $\begin{array}{c}\text { Push shoulder } \\
\text { strength (kg) }\end{array}$ & 15,4 & 15,9 & 0,5 \\
\hline 4 & $\begin{array}{c}\text { Pool shoulder } \\
\text { strength (kg) }\end{array}$ & 19,2 & 20,6 & 1,4 \\
\hline 5 & Aerobic endurance & 31,2 & 34,1 & 3,0 \\
\hline
\end{tabular}

\section{Normality Test}

Normality test aims at testing whether a data set has a normal distribution. For this specific purpose, this study applied the Kolmogorov-Smirnov Z formula. Results of the normality test are summarized in the following table.

TABLE II. NORMALITY TEST

\begin{tabular}{|c|l|l|c|}
\hline \multicolumn{2}{|c|}{ Variable } & Sig. & Keterangan \\
\hline \multirow{2}{*}{ Leg strength } & pretest & $0,883>0,005$ & Normal \\
\cline { 2 - 4 } & Posttest & $0,753>0,005$ & Normal \\
\hline \multirow{2}{*}{ Back strength } & pretest & $0,966>0,005$ & Normal \\
\cline { 2 - 4 } & Posttest & $0,967>0,005$ & Normal \\
\hline \multirow{2}{*}{$\begin{array}{c}\text { Push shoulder } \\
\text { strength }\end{array}$} & pretest & $0,967>0,005$ & Normal \\
\cline { 2 - 4 } & Posttest & $0,693>0,005$ & Normal \\
\hline $\begin{array}{c}\text { Pool shoulder } \\
\text { strength }\end{array}$ & pretest & $0,995>0,005$ & Normal \\
\cline { 2 - 4 } & Posttest & $0,990>0,005$ & Normal \\
\hline \multirow{2}{*}{\begin{tabular}{c} 
Aerobic endurance \\
\cline { 2 - 4 }
\end{tabular}} & pretest & $0,953>0,005$ & Normal \\
\cline { 2 - 4 } & Posttest & $0,977>0,005$ & Normal \\
\hline
\end{tabular}


From the above table, significance levels (p) of all variables are greater than 0.05 and therefore indicate normal distribution. As all data are normally distributed, analysis using parametric statistics could be continued.

\section{Hypothesis Test}

The hypothesis test in this research aims at finding answers for the hypothesis. It was carried out to examine the acceptance and rejection of the proposed hypothesis making use of a t-test (paired sample t-test) with $5 \%$ significance level. Results of the hypothesis test (t-test) are presented in the following table:

TABLE III. RESUlts OF HyPOTHESIS TEST (T-TeST)

\begin{tabular}{|c|c|c|c|}
\hline $\begin{array}{c}\text { Pretest- } \\
\text { posttest }\end{array}$ & t count & Sig. & Information \\
\hline Leg strength & 2,718 & $0.17>0,005$ & $\begin{array}{c}\text { No significant } \\
\text { influence }\end{array}$ \\
\hline Back strength & 0,295 & $0,772>0,005$ & $\begin{array}{c}\text { No significant } \\
\text { influence }\end{array}$ \\
\hline $\begin{array}{c}\text { Push shoulder } \\
\text { strength }\end{array}$ & 0,208 & $0,838>0,005$ & $\begin{array}{c}\text { No significant } \\
\text { influence }\end{array}$ \\
\hline $\begin{array}{c}\text { Pool shoulder } \\
\text { strength }\end{array}$ & 1,00 & $0,331>0,005$ & $\begin{array}{c}\text { No significant } \\
\text { influence }\end{array}$ \\
\hline $\begin{array}{c}\text { Aerobic } \\
\text { endurance }\end{array}$ & 3,60 & $0,003<005$ & Significant influence \\
\hline
\end{tabular}

Results of the hypothesis test using a t-test show that aerobic fitness physical biomotor is the only component whose influence is significant $(\mathrm{t}=3.60, \mathrm{p}=0.003<0.005)$. After treatment, there is an increase of $9.62 \%$ in aerobic fitness motor abilities. However, there is no significant influence on strength biomotor as its significance level is greater than 0.005 .

\section{Discussion}

Results of this study present various outcomes of the given treatment. Referring to differences in mean, all components of motor abilities increase. However, the hypothesis test suggests that not all of them are significant. The aerobic fitness increases significantly. The treatment was to maintain the heartbeat rate at $60 \%$ to $70 \%$ of its maximum rate. It was conducted in sand volleyball court for 40 to 60 minutes. During the implementation, the average athletes reach seventy percent of their maximum heart rate. Though this program focuses on aerobic fitness training, it can also be seen that the strengths of limb, back, and shoulders increase as well. But, their increases are not statistically significant. It's indicated by the mean differences of limb strength (23.1 $\mathrm{kg}$ ), back strength (8.7 kilograms), push shoulder strength $(0.5 \mathrm{~kg})$, pull shoulder strength (1.4 kilograms).

Limb strength increases along with a $23.1-\mathrm{kg}$ difference in mean. The training was performed in the sand using various moves and the addition of a 5-kilogram weight. The move is a change of plank but with hands holding the iron. Plank-combination moves train flexor muscles greatly and stimulates extensors at articulation coxae, the articulatio genus to work extra.

After a few treatments were given during the back training, back muscle strengths as well as increase. Moves in the trunk stimulate the extensor muscles of the trunk. Though, mean differences suggest that the increase is not as high as that of limb strength. It is because of the fact that trunk muscles are treated less intensively than limb muscles.

Pull and push shoulder strength increases a little bit or as high as 0.5 kilograms and $1,4 \mathrm{~kg}$ as seen in differences in posttest and pre-test means. The given treatment is considered less intensive to train muscles for pulling and pushing on shoulders (musculus trapezius, musculus pectoralis major, minor). Additional weight is placed more on the shoulders; though, some moves that utilize muscles to pull and push on shoulders are lack of training. In other words, musculus trapezius, musculus pectoralis major, musculus pectoralis minor get lack of training simulations.

Molecularly, performing strength as well as endurance training simultaneously will potentially interrupt the development of strength. Such disruption is caused by changes in adaptive protein synthesis as a result of endurance training, too much training, and some unidentified factors. New technology helps to understand the molecular mechanism in skeletal muscles adaptation induced by the training (e.g. gene expression genome-wide analysis) [1].

\section{CONCLUSION}

A combination of aerobic fitness and strength training collectively performed by athletes aged thirteen to fourteen years old has the significant influence on aerobic fitness. Though, results show no significant influence of the training on strength due to a potential disruption in strength development. Such disruption is mainly caused by changes in adaptive protein synthesis as a result of endurance training.

\section{REFERENCES}

[1] G. A. Nader, "Concurrent strength and endurance training: from molecules to man. Medicine \& Science in Sports \& Exercise," Vol 38, No. 11 pp.1965-1970. 2006.

[2] D. G. Sale, J. D. Mcdougall, I. Jacobs, And S. Garner. "The interaction between concurrent strength and endurance training," J. Appl. Physiol. 1990. 68:260-270.

[3] G. A. Dudley, R. Djamil, "Incompatibility of endurance- and strengthtraining modes of exercise," J Appl Physiol 1985; 59: 1446-51

[4] R. C. Hickson, "Interference of strength development by simultaneously training for strength and endurance," Eur J Appl Physiol 1980; 45: 255-63

[5] W. J. Kraemer, J. F. Patton, S. E. Gordon, et al. "Compatibility of high-intensity strength and endurance training on hormonal and skeletal muscle adaptations," J Appl Physiol 1995; 73: 976-89

[6] R. M. Malina, J. C. Eisenmann, S. P. Cumming. et al Maturity-associated variation in the growth and functional capacities of elite youth football (soccer) players 13-15 years. Eur J Appl Physiol 2004, 91555-562.

[7] L. Hansen, J. Bangsbo, J. Twisk et al, "Development of muscle strength in relation to training and level of testosterone in young male soccer players," J Appl Physiol 1999871141-1147.

[8] R. J. Shephard, "Biology and medicine of soccer: an update," Sports Sci 1999; 17: 757-86

[9] J. Bangsbo, Physiological demands. In: Ekblom B, editor. Football (soccer). London: Blackwell, 1994: 43-59logical

[10] F. J. Monks, Psikologi Perkembangan: Pengantar Dalam berbagai Bagiannya. Cet. 14.: Yogyakarta: Gajah Mada University Press; 2002

[11] J. R. Ducharne, M. G. Forerst, "Normal pubertal development. Dalam: J. Bertrand, R. Rappaport, P. C. Sizonenko, penyunting. Pediatric Endocrinology. Edisi ke 2.

[12] Baltimore: William; 1993.h.372-86.13.Tanner JM. Foetus into Man. Edisi ke-2. Inggris: Castlemead Publication,198 